\title{
10 The Economic, Social, Ecologic, and Psychological Background of the Company-Relevant Stakeholders-Based Management
}

\section{Holistic Approach to the Company-Relevant Stakeholders-Based Management System Foundations}

Our research, from the beginning, has been based on a holistic approach to the environment, company, stakeholders and management. Today, such a vision and approach are mandatory in every research, because without them it is not possible to "grasp", take into consideration, analyse and design realistic and performant solutions to any major problem.

We continue to apply this vision and approach to the causes that make possible and necessary the company stakeholders-based management system. We focus on the essential causes involved, causes that we call the foundations of the company-relevant stakeholders-based management system. According to our analysis, there are four essential foundations (see Figure 10.1):

First, there is the economic foundation. The company is the main organizational component of each national economy. Most economic activities are developed in companies. Almost all products and services necessary for the society are produced by companies. Most of the value added of the national income in any country is generated in companies. In recent decades, companies have faced many new business situations and many economic challenges.

In our opinion, the main economic challenges for companies are generated by the transition from the "classical value chain" to new types of value chains, mainly virtual value chains. The main difference between the "classical value chain" and the virtual value chain is that the latter is more comprehensive, incorporating not only company activities but also outside activities accomplished by external relevant stakeholders - customers, suppliers, intermediaries, investors, bankers, designers, etc. The virtual value chain includes not only physical activities but also information and knowledge processes. Virtual value chains, which proliferated rapidly in companies, are associated with new and very complex problems regarding the value creation and appropriation in a company with multiple stakeholders. 


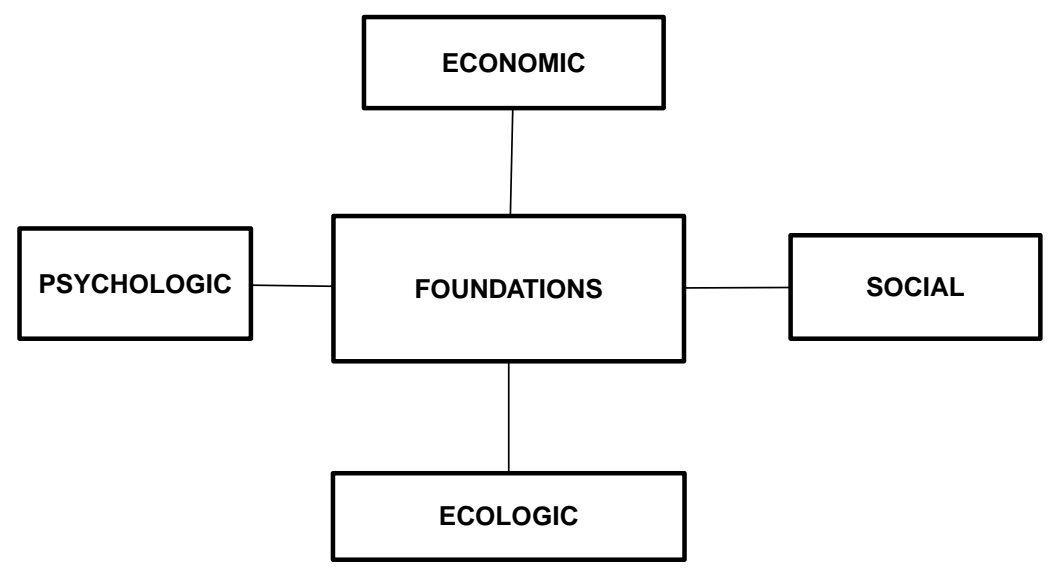

Figure 10.1 Foundations of the company-relevant stakeholders-based management system.

Company management, in order to be able to manage in a performant manner both inside and outside virtual chain activities, which are much more complex and dynamic than the "classical" ones, needs a stakeholders management system. Relevant stakeholders, both internal and external, integrated in managerial synapses are the key players capable of developing virtual value chains.

Social causes represent the second type of foundation. A company, like any other organization, means firstly people. It is composed of individuals who fulfil all necessary inside activities. Multiple and essential external company relations are also fulfilled by the company's own human resources and people representing other outside entities - external relevant stakeholders. All these social relationships are very influential on the company's activities and performance. All these social relationships depend on the persons involved, on their characteristics, feelings, motivations, involvement, satisfaction, engagement, and others. In order to be performant, the company should be able to take all these aspects into consideration, and manage them in efficient and sustainable ways. Hence, companies need new managerial approaches, different from the classical ones. A company stakeholders-based management system represents a possible realistic solution to these social challenges, involving all relevant internal and external stakeholders.

Ecological challenges represent the other essential category of problems that increasingly influence the company's activities and performances. Today, ecological factors have become very important at all levels of the society and economy, starting with the individual person, continuing with all kinds of organizations and up to the level of mankind. Important parts of the society have realized the determinant impact 
of ecological factors on the world's present and future existence and development. Many communities and NGOs have very useful and numerous ecological initiatives and actions. A large proportion of them are directed at the company level, where most natural resources are used, and where the majority of activities that have an impact on the ecologic environment are fulfilled. In this context, companies should face new types of challenges and deal with many new elements ignored in the previous period. The use of all material resources, protection of the environment, avoidance of pollution and of energy and raw material waste, material recovery, recycling, and reuse have become strategic challenges for any company. The management of a company should deal permanently with these aspects and find and implement the right solutions from ecologic and economic points of view. In order to do this, companies need a new type of management with a strong ecological dimension capable of facing new challenges and finding efficient ecological solutions. A company stakeholders-based management system incorporates the vision and the tools that are able to respond to a large extent to these challenges.

Many companies have already started to generate and implement new approaches focused on social and ecological problems. Corporate social responsibility represents the most widely used approach in trying to solve major social and ecological problems. Corporate social responsibility, developed in the last few decades, promotes a new company approach and behaviour regarding some of the most important company stakeholders society, the ecological environment, local communities, customers, clients, and their own employees. Without any doubt, significant progress has been made in many companies, especially in corporations. But the holistic, permanent, and performant approach and resolution of social and ecological problems remain a huge challenge in companies and also a keen need. A company stakeholders-based management system contains the necessary new decisional, actional, and behavioural elements that are able to satisfy this need.

Human resources, in today's companies, have to a large extent a high level of education, knowledge, and aspirations. Actual company employees are quite different from the labour force employed a few decades ago, and have a different psychology. The typical component of the contemporary company tends to be a highly educated person, possessing a lot of knowledge, with a large array of interests and expectations, possessing valuable intellectual capital, quite often aware of their potential, and demanding to be treated in a new manner. Organization employees and external stakeholders expect from the company management a totally new approach that is able to take into consideration their psychological particularities and satisfy specific human and work requirements. Company management, in order to integrate the employees and other stakeholders, to stabilize them and to increase their 
efforts, satisfaction, creativity, and productivity, should offer new types of approaches and solutions, focused on the human side of people's personality. In this context, management practice and theory have developed humanistic management. $^{1}$

Other essential elements, closely associated with humanistic management, include the reconsideration of people's emotions and emotional intelligence, helping to promote another individual treatment of these people, much more suited to the individual characteristics of the internal and external company stakeholders. Studies of emotions and emotional intelligence provide better psychological premises in organizations to understand, communicate, and cooperate with the human resources. Humanistic management, the study of emotions and emotional intelligence, has made notable contributions toward a better treatment of employees with beneficial results for the quality of work, manager behaviour, work climate, and individual and organizational performances.

But the reality shows us that these new managerial and psychological approaches are used just in a small number of companies - more frequently in corporations - and usually they are not employed systematically, not integrated in a holistic strategic vision addressed to all company-relevant stakeholders. In order to fully valorize humanistic management, the study of emotions, emotional intelligence and other new elements regarding the "human side" of human resource, they should be integrated in a new management system capable of taking into consideration permanently these "delicate" human aspects. A companyrelevant stakeholders-based management system, having a managerial synapse as an essential component, tailored to the specifics of both components, might be able to largely solve these psychological aspects, with significant positive effects on individual and organizational company stakeholders.

Economic, social, ecologic, and psychologic foundations should be approached holistically, taking into consideration the multiple interrelated influences and effects at the level of the whole company and its relevant stakeholders, including the new elements generated by the COVID-19 pandemic. In the following sections we shall deal with each of the main foundations, emphasizing the causal connections between them and the company stakeholders-based management system.

\section{Value Creation and Appropriation in a Company with Multiple Relevant Stakeholders}

In our approach we start from the stakeholder-based perspective of performance, defined by Harrison and Wicks (2013, p. 108) "as the sum of the utility created by the firm for legitimate stakeholders". In the definition we make one change, replacing the "legitimate" stakeholders 
with the "relevant" stakeholders, in accordance with our vision regarding management based on relevant stakeholders. We will not make reference to another three popular stakeholder company performance perspectives - Shareholders-Based Financial Performance, the Balance Scorecard, and the Triple Bottom Line - because they are not directly in line with the profile of this paragraph, focused on the economic background of the company stakeholders-based management system (Harrison, Bosse, \& Phillips, 2010; Lieberman, Garcia-Castro, \& Balasubramanian, 2017; Tantalo \& Paton, 2013).

Our approach is based on the following four perspectives:

a Value created in the company is generated both by the enterprise and its stakeholders;

b The virtual value chain is the main mechanism of the company stakeholders' value creation;

c Each company has and develops relationships with a stakeholder only if it creates value for the organization or the stakeholder facilitates directly or indirectly the value added creation;

d It is a positive relationship between stakeholders-oriented management and economic firm performance, which can be almost always measured in terms of financial returns (Choi \& Wang, 2009; Dorobantu \& Odziemkowska, 2017; Hillman \& Keim, 2001).

Relevant stakeholders can contribute to the value creation in a company in many ways: providing some resources (equipment, work, land, buildings, money, etc.), having knowledge and using it in the company's activities, possessing and using special competences in the company, providing to the company certain commercial, financial, technical, etc. services. The contribution of the stakeholder to the company's performance is one criterion in the evaluation of its relevance. The most relevant stakeholders are parts of the virtual value chain and usually make a bigger contribution to the company's performance.

Many specialists (Amit \& Zott, 2001; Bosse, Phillips, \& Harrison, 2009; Bowman \& Ambrosini, 2000; Brandenburger \& Stuart Jr., 1996; Lepak, Smith, \& Taylor, 2007) have contributed to the elaboration of the concept regarding stakeholders' contribution to company performance and their rewarding for this contribution, called value creation appropriation (VCA) in the company. Stakeholders are treated as claimants and capturers of value in their interaction with the company. In recent years there has been a change from the neoclassical economic model, based only on two relevant stakeholders (the consumer and the producer), to the broader-based view of value creation appropriation, where multiple stakeholders are considered. Garcia-Castro and Aguilera (2015) make a remarkable contribution in this respect. They developed a conceptual framework based on an analytical taxonomy of value 
creation and appropriation "consistent with a more complex notion of value and wherein the trade-offs in stakeholders' value appropriation are included". The concept of total value created by the firm and all its stakeholders is used, instead of the previous concept of shareholder value creation. Based on this comprehensive approach of total value creation in the company, they elaborated a model value creation and appropriation with multiple stakeholders.

One important practical aspect is the possibility of applying this model to a company, only using publicly available data referring to prices, costs, inputs, and outputs. This framework could be utilized in order to measure and redistribute the total value created in the firm to the relevant stakeholders. Moreover, it is based on another new concept introduced by Garcia-Castro and Aguilera (2015), value creation elasticity of stakeholder value appropriation, which captures the relationships between value appropriated by a stakeholder and the total value added in a period of time. This approach makes it possible to assess whether each dollar appropriated by one stakeholder has a positive, neutral or negative effect on the total value created by the company. According to the authors, value creation appropriation elasticity could be used by company decision-makers to fulfil voluntary investments by selected stakeholders, in order to maintain distributional justice, respect reciprocity norms, and build trustworthiness.

Without any doubt, value creation appropriation elasticity represents a very good approach for companies in order to manage much better relevant stakeholders, taking into consideration their contribution to the total value created in the firm. In its use it is important to take into consideration the limits of the approach, which have been outlined by Castro and Aguilera themselves.

Company-relevant stakeholder management - in order to use the possibilities created by value creation appropriation elasticity and by other innovative approaches in this field - needs an appropriate accounting. According to the specialists Mitchell, Van Buren, Greenwood, and Freeman (2015), stakeholders' inclusion in organizational decisionmaking and the resulting issue of value creation is one of the thorny problems that stakeholder management has sought to address. A new branch of accounting is needed that is able:

- to identify the contribution of each relevant stakeholder to the creation of the total value in the company and to reflect it in accounting;

- to allow appropriation of the value allocated to each relevant stakeholder from the company value.

In this regard, some steps ahead have been made, but slowly and not enough. There have been some promising studies in the last few years. 
One of them (Mitchell et al., 2015) developed a transdisciplinary theory of value creation stakeholder accounting. This is based on stakeholder risksharing as a superior rationale for stakeholder inclusion. In it is proposed a new mechanism - the value creation stakeholder partnership - for implementing the new type of stakeholder accounting. The new mechanism is a creative combination of accounting value creation, entrepreneurship, and stakeholder theory. In a special issue of a renowned management journal, ${ }^{2}$ a set of papers were consecrated to this essential field for company stakeholder management.

The development of the special accounting mechanism that is able to reflect both value contribution and appropriation of each relevant stakeholder in the company is necessary in order to build a performant managerial synapse and stakeholders-based management system.

The elements presented ensure that the company-relevant stakeholdersbased management system applies the principles of distributional, procedural, and interactional justice (Harrison et al., 2010), which is essential for the organization relevant stakeholders' engagement and performance.

\section{Value Chain and Virtual Value Chain}

The virtual value chain - the main mechanism of the company stakeholders' value creation - represents one of the four premises of the value creation and appropriation approach mentioned in the first paragraph of this chapter. A value chain - as outlined by the very well-known specialists Freeman and Liedtka (1997) - should and could be interpreted in stakeholders' terms.

The value chain concept was created and launched in the managerial theory and practice by Michael Porter in his famous book in 1985 (Porter, 1985). Value chains have had a huge impact on business and company management. A value chain is a set of activities that a company, operating in a specific industry, performs in order "to deliver" valuable products or services for market. These activities are divided into two categories:

a primary activities - inbound logistics, operations, outbound logistics, marketing, sales and services;

b support activities - infrastructure, technological development, human resource management and procurement.

A value chain is a powerful management tool for disaggregating a company into its strategically relevant activities, in order to focus on the sources of competitive advantage.

It has revealed the essential role of two categories of external company relevant stakeholders - customers and suppliers - by including them in the primary activities of the company and also by their strong 
involvement in support activities. Such an approach has had a major impact on reorganizing, in a practical manner, the contribution of these relevant stakeholders to the value creation in the company and on the need to give much more attention, effort, and resources in cultivating special relationships with them.

From the Porter value chain many new variants of value chains have been developed, adapted to the different industries and companies. In 1995, Rayport and Sviokla created a virtual value chain reflecting the profound changes produced in the company, economy, and society, generated mainly by the knowledge revolution and the transition to a knowledge-based economy. They conceived a virtual value chain bearing in mind that every business today competes in two worlds: a physical world of resources that managers can see and touch, and a virtual world made of information (Rayport \& Sviokla, 1995).

A virtual value chain is an integrated system rather than a set of related activities; it incorporates five generic value adding steps, which are virtual in that they are performed through and with information on each activity in the value chain:

- gathering, by sifting and extracting, digital information

- organizing, by storing the information in special ways, making it easy to retrieve and use it

- selecting, by choosing the information, to add value to the operation

- synthesizing, by placing the information into context for users

- distributing, through transmission of synthesized information to users

Usually, a virtual value chain represents the results of combining physical and virtual value chain analysis.

The virtual value chain is non-linear; it represents a matrix of potential inputs and outputs that can be accessed and distributed through a wide variety of channels involving a large array of company-relevant stakeholders. Management could use separately the value chain and, respectively, the virtual value chain. In order to maximize performance, it is recommended to use both value chains correlated or - better still combining them.

In Figure 10.2, we present a variant of virtual value chain which is frequently used in the management company (Van Vliet, 2010; Weiber \& Kollmann, 1998). This variant is a combination of a physical value chain and a virtual actual value chain.

Rayport and Sviokla (1995) recommend to company managers a set of five guiding principles in the use of a virtual value chain, alone or in combination with a physical value chain: 


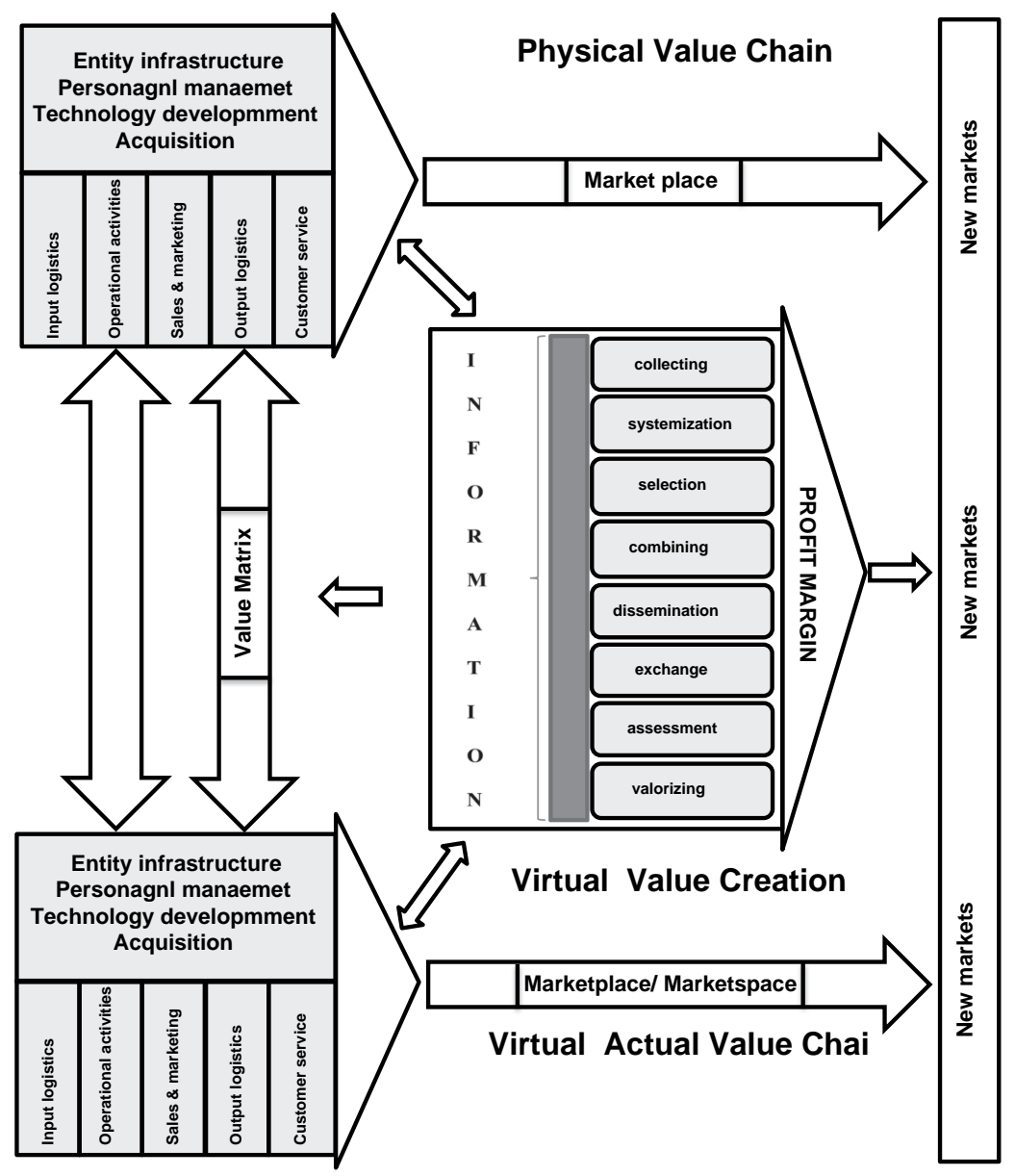

Figure 10.2 Virtual value chain.

Adapted from Virtual value chain model, by V. Van Vliet, 2010. Retrieved from https:// www.toolshero.com/problem-solving/virtual-value-chain/.

- the law of digital assets

- new economies of scale

- new economies of scope

- transaction cost compression

- rebalancing supply and demand

The potential main advantages of company management focused on a virtual value chain - which could be greatly amplified by using a stakeholders-based management system - are the following: 
- physical operations become more effective through a large-scale information system, used to coordinate activities in the physical value chain;

- substitution of physical activities with virtual activities, creating a parallel virtual value chain in the marketplace for the company, which could increase the market share and the sales;

- team that deals with company value chain can transcend the limitations of time and space that characterize the management of physical activities;

- information extracts in every stage of the virtual value chain can be turned in new spin-off products or services;

- placement of the company in a better position in the total value industry process, based on the previous advantages generated by its virtual value chain;

- increase of the company's interorganizational competitive advantage in the context of co-opetition.

Organization management, using a company-relevant stakeholdersbased management system, can gain and increase all these advantages at a superior level of performance because:

a every relevant activity, every component of the value chain, is fulfilled by a relevant stakeholder, who can be managed in a more performant manner if he/or she is integrated in a managerial synapse;

b the value chain selects and incorporates not only the relevant activities for total company value creation, but, implicitly, the relevant stakeholders; this helps in the evaluation of company stakeholders' relevance and, based on this, in integrating them in a managerial mechanism - a stakeholders-based management system;

c a value matrix specific to the virtual value chain - which represents in fact a matrix of value opportunities - can generate more value for the company and its partners if it is used with a stakeholders-based management system focused on the relevant stakeholders, which in fact could approach and valorize the new opportunities within the value chain;

d a virtual value chain moves relevant activities totally, or a large proportion of them, from the traditional market to the marketplace, increasing the dependence of the performance from the external and internal relevant stakeholders. A stakeholders-based management system can be very useful in the development and fructification of very powerful relationships with these categories of relevant stakeholders;

e a company-relevant stakeholders-based management system due to its specific features - joint objectives, win-win negotiations, 
reciprocity, etc. - is much more suited to determining the human resources fulfilling the relevant chain of activities, which in fact are company-relevant stakeholders, to operate in new ways required by the virtual value chain.

The value chain and virtual value chain are two economic systems that integrate relevant activities - physical and/or information - fulfilled by relevant internal and external company stakeholders. Consequently, we can conclude that both value chains, in order to generate consistent competitive advantage, need a company-relevant stakeholders-based management system.

\section{Knowledge Value Chain}

Without any doubt, a knowledge value chain is essentially a virtual value chain. The creation of this specific knowledge value chain has been determined by several causes (see Figure 10.4).

Four main reasons have motivated us to approach it separately, in a special section:

a it presents many very important particularities, which make it different from the consecrated value chain and virtual value chain;

b there are certain categories of companies, especially eco-enterprises like network companies, virtual enterprises, etc. - in which there are not any physical activities, as all work processes are knowledge processes. In these companies, only the knowledge value chain operates;

c in the future starting with the near future - the knowledge-based companies where only knowledge work processes operate will increase in number very fast and will have a greater impact on business functioning and performances;

d transition to a knowledge-based economy, determined by fast digital transformation, nanotechnologization, biotechnologization, human resources transformation, etc., will increase the frequency and performance of the networks of knowledge value chains at the level of industry, national economy and global economy.

In Figure 10.3, we present the generic knowledge value chain adapted from the variant elaborated by Holsapple and Singh (2001), as cited in Holsapple and Jones (2004).

Knowledge value chain creation and fast development are determined by several causes presented in Figure 10.4 (Nicolescu \& Nicolescu, 2011).

A knowledge value chain is a knowledge management framework (Lee \& Yang, 2000) that can contribute to a large extent to increasing the value added generated by the company and its relevant stakeholders. 


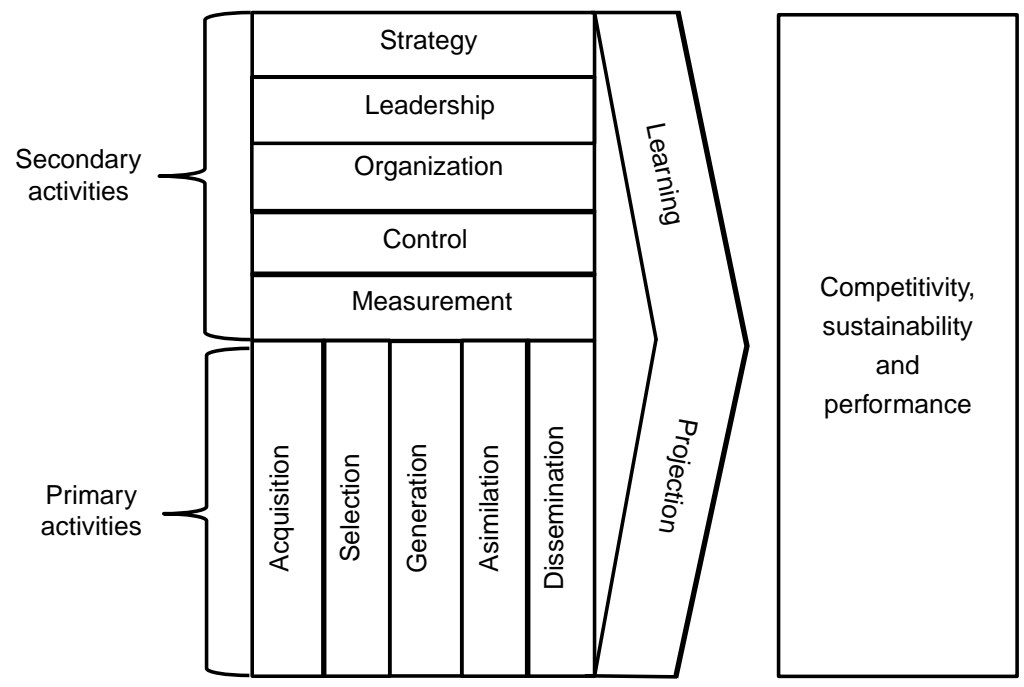

Figure 10.3 Knowledge value chain.

Adapted from "Knowledge chain model: Activities for competitiveness" by C. W. Holsapple \& M. Singh, 2001, Expert Systems with Applications, 20(1), p. 80. Retrieved from https://doi.org/10.1016/S0957-4174(00)00050-6.

A knowledge value chain, compared with a virtual value chain, has certain particularities (see Table 10.1) that are useful in company management.

The particularities show that the knowledge value chain has huge potential for value creation in companies, through work processes focused on knowledge transformations - creation, access, use, share, organization, dissemination, protection, etc. These knowledge processes generate high performances when they use the tacit and explicit knowledge of all company-relevant stakeholders. The new stakeholdersbased management system could help to achieve them successfully. A knowledge value chain focused on knowledge capital (Ermine, 2013), the strategical resource of a company, is - without any doubt - the value chain of the future, in the knowledge-based economy, which is rapidly developing in the context of digitalization.

Taking into consideration the elements regarding the knowledge value chain and virtual value chain, we can conclude that the economic background of modern company management has changed (see Figure 10.5). The new economic background of the modern company - a knowledge-based company - is represented by the virtual value chain and knowledge value chain. In order to be performant, managers of the company should focus their decisions and actions on these value 


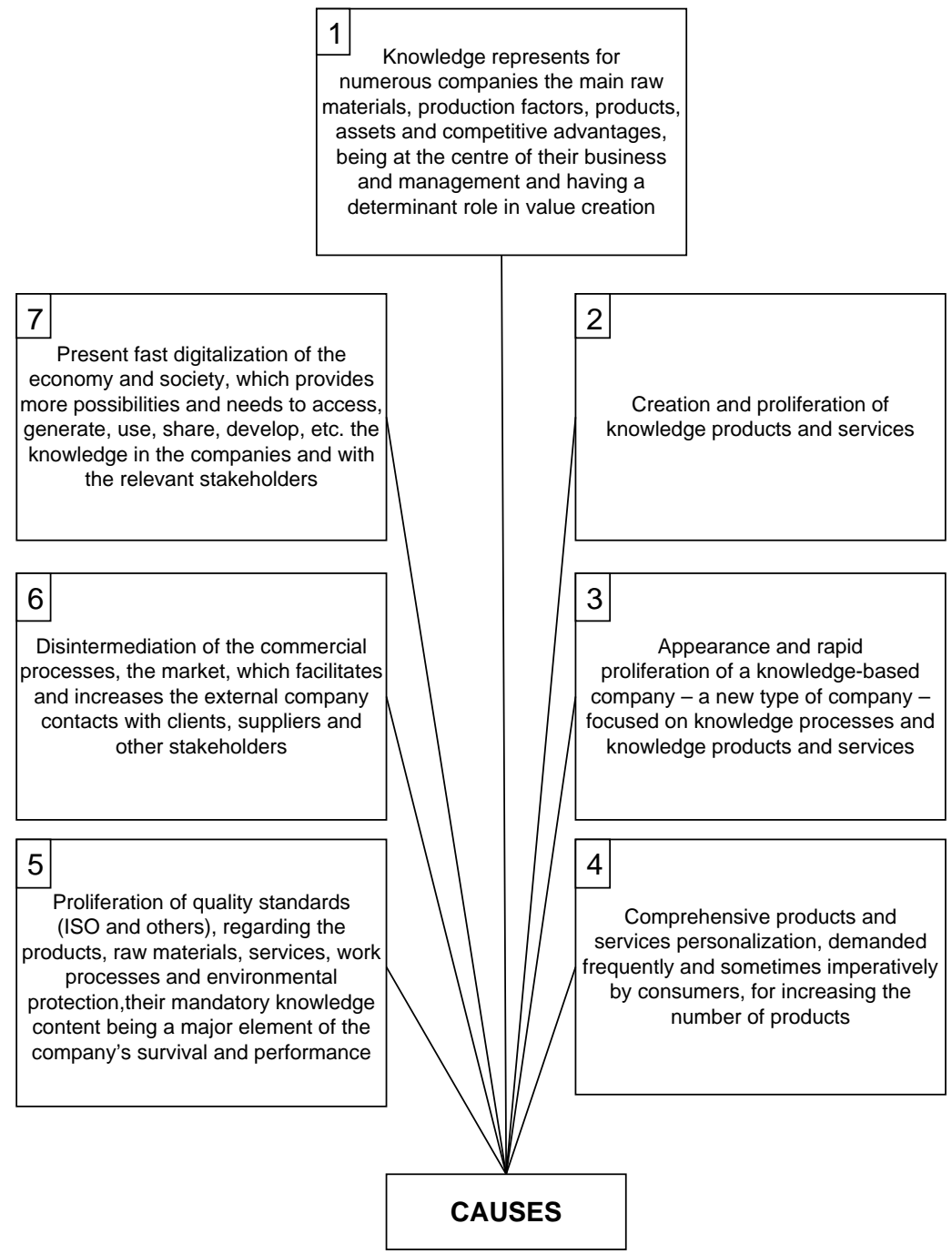

Figure 10.4 Main causes of knowledge value chain creation

chains and on the internal and external relevant stakeholders who operate them.

\section{Interdependencies Between Company Value Chains - Business Environment-Relevant Stakeholders}

Approaching each type of value chain separately - as we did in the previous sections - provides only a limited understanding of their role in 
Table 10.1 Main particularities of the knowledge value chain

No. Particularities

1. It works in a new type of enterprise - a knowledge-based company characterized by the fact that knowledge represents the main raw material, production factor, asset, product, and competitive advantage

2. It deals only with knowledge products, or products very rich in knowledge

3. It incorporates only knowledge processes from within the company or outside the company; the most frequent company knowledge processes are the identification, creation, acquisition, organization, sharing, learning, storing, protecting, and selling of the knowledge

4. It is based on a strong IT background, which is permanently and rapidly developed

5. It is operated mainly by a new type of human resource - a knowledgebased employee - with rich knowledge and a high capacity to process knowledge and generate value added

6. It flexibly integrates certain activities from outside the company

7. It is very dynamic, rapidly operating, and modifying, because of the fastchanging VUCA environment

8. It involves very specific economic, management, and human structures and approaches, many of them structured as a network

9. It operates in the marketspace and in the environment space, not directly in the classical marketplace

10. It is connected with a lot of other knowledge and/or virtual value chains of suppliers, customers, investors, bankers, consultants, designers, etc., being part of many networks of value chains

11. It is a very performant system, based on the knowledge capacity to be used concomitantly in many places generating value added

12. It enables the integration of the company and its relevant stakeholders in the industry, markets, global value chains, etc.

companies and the economy, and of the relevant stakeholders' implication. In Figure 10.6, we try to present the main relationships between the transition from one type of value chain to another, the main components of the business environment involved and the categories of relevant company stakeholders directly participating in the activities generating value added in the company. The premises of our analysis are the following:

- a value chain represents not only a system of relevant activities but also a network of relevant stakeholders;

- certain components of the company business environment - not only the market - greatly influence the capacity to produce value added for the value chain, relevant activities, and the relevant company stakeholders. 


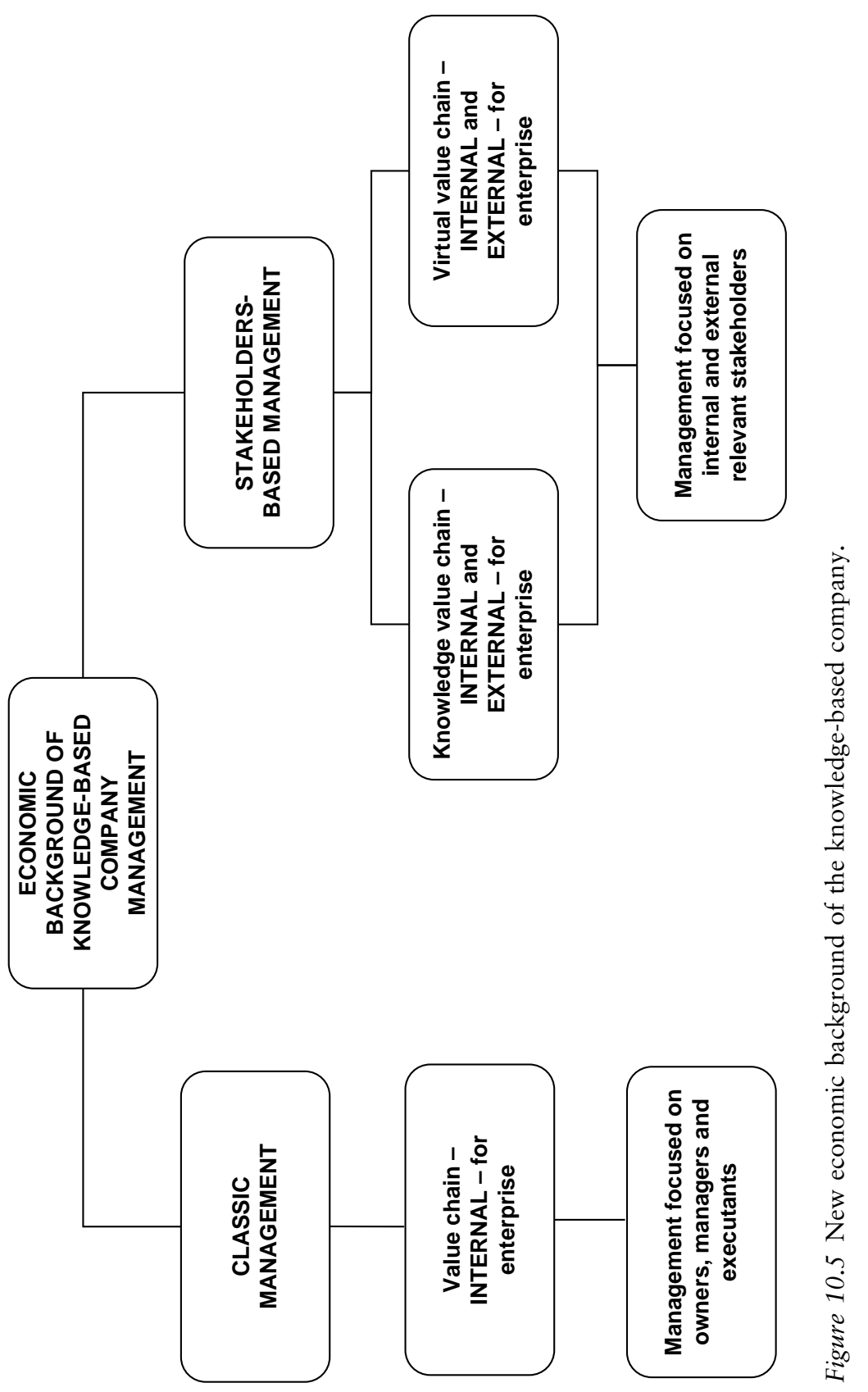




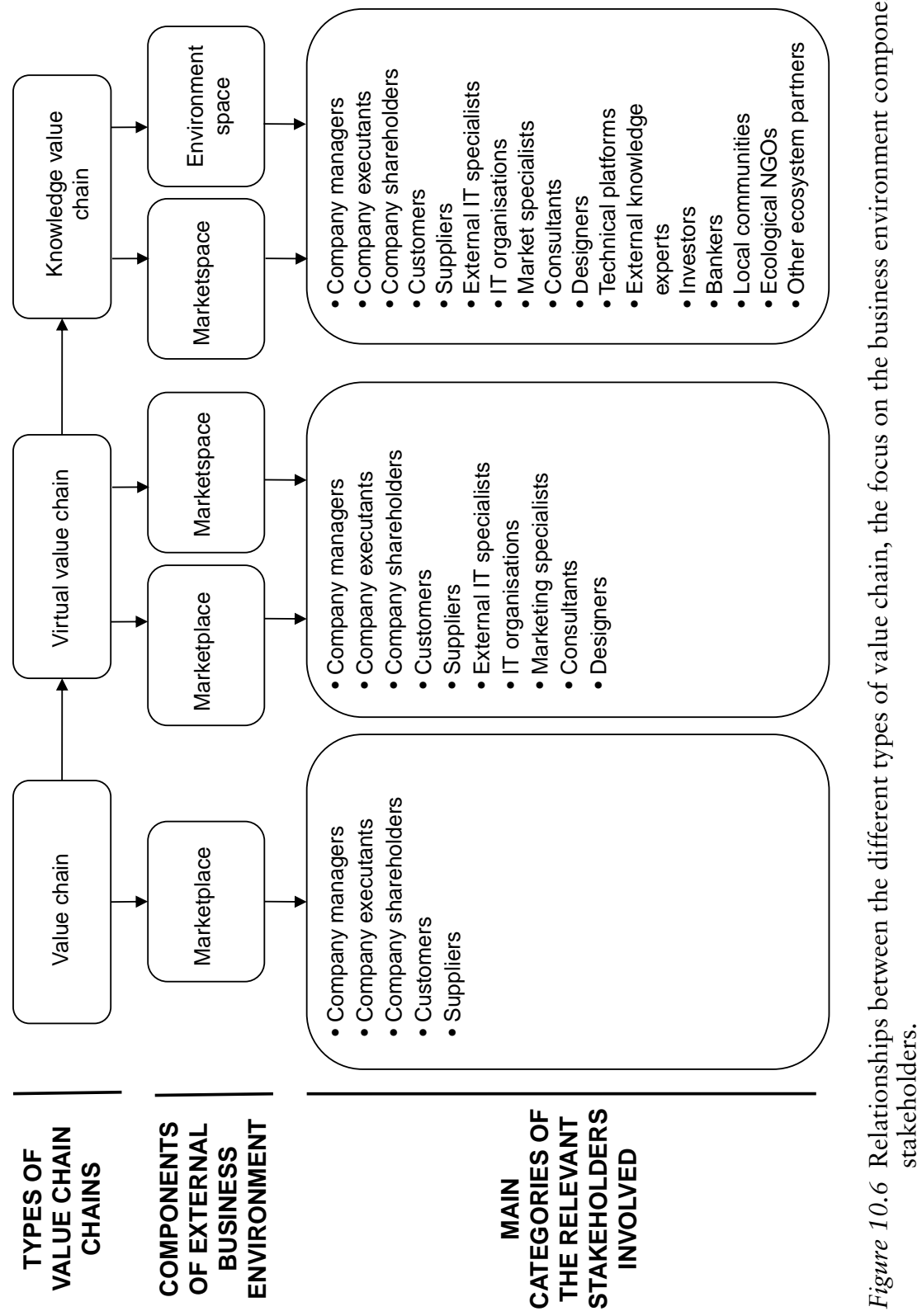


Certain specialists (Lin \& Wu, 2010) on the virtual value chain have introduced the marketspace approach, which incorporates virtual processes based on the use of information, by the company, in order to sell its products and services on the market. Our analysis has indicated that on the knowledge value chain activities has an increasing impact - positive or negative from profit point of view - many others components of the environment - labor market, local community, company industry, capital market, banking system, ecosystems involved, or industrial platforms. They participate in the company value chain activities, directly and indirectly, with knowledge, which is value chain content that is absolutely essential for the company to gain competitive advantage and be performant. For this reason, we propose the new approach of environmentspace, which includes, besides marketspace - which remains a milestone element of a value chain - all other environment components participating in the company knowledge value creation. Environmentspace is the knowledge area outside a company where external parts of the knowledge value chain activities operate that are absolutely essential for the organization's survival and competitive performance. Company access to the environmentspace provides an important part of the tacit and explicit knowledge used within the value chain, sometimes very innovative, from the creative external relevant stakeholders. Environmentspace is an essential element of the company's integration in economy networks, in its ecosystems.

Analysis of the elements incorporated in Figure 10.6 indicates the following main conclusions:

a the first horizontal axis indicates the changing of the type of value chain: from the classical value chain focused on physical activities to the virtual value chain focused, totally or partially, on the virtual activities creating value added, and to the knowledge value chain, focused on the knowledge activities generating value added through high utilization and valorization of the company and relevant stakeholders' knowledge;

b the second horizontal axis indicates the changes in environment components, where the value chain operates; it starts with marketplace, the external company area of action of the classical value chain, goes on to marketspace alone or combined with virtual marketplace and, finally, environmentspace, which incorporates all virtual components of the company environment, where a knowledge value chain operates;

c stakeholders are usually involved in each type of value chain; this axis shows the increasing number of company-relevant stakeholder types that participate in the operation of relevant chain activities, enriching their capacity to generate more added value; 
d the first vertical axis indicates that the classical value chain acts outside the company mainly in the marketplace and the principal categories of relevant stakeholders involved - managers, shareholders, executants, customers, and suppliers;

e the second vertical axis shows that a virtual value chain works in the business environment, both in marketplace and marketspace, involving more categories of external company-relevant stakeholders; the new categories of external stakeholders are: IT specialists, IT organizations, virtual marketing specialists, consultants, and designers;

$\mathrm{f}$ the third vertical axis indicates that the knowledge value chain operates not only in the marketspace but also in the environment space, which includes, as we have demonstrated, other important parts of the company environment. Compared with a virtual value chain, in the knowledge activities generating value added more categories of relevant individual and organizational stakeholders can participate, such as technological platforms, external knowledge experts, investors, bankers, local communities, ecological and social NGOs, and other company ecosystem partners.

The horizontal axis indicates the essential development of the company value chain as a system (first axis), and the changes in the approach of the company environment components, and of the relevant stakeholder categories (third axis). The horizontal axis reveals the major progress of the company value chain approaches in itself and from the perspective of company environment and relevant stakeholders.

The vertical axis shows the essential differences between the three types of value chains and, because of these, the need to adopt different managerial approaches, taking into consideration the environment parts and the relevant stakeholders involved. Each type of value chain needs special managerial mechanisms focused on the relevant activities creating value and on the relevant stakeholders possessing valuable information and knowledge and operating value chain activities.

One final remark: in the economy there are and will be all three types of value chains, reflecting the heterogeneity of companies and the environment. It is a company management duty to select and to apply the type of value chain suited to each company, using special managerial mechanisms that are able to produce high performance, like a managerial synapse and/or a stakeholders-based management system, and to adopt the management tools that generate high performance. Of course, there is a strong tendency to proliferate the virtual value chain and knowledge value chain, the most up-to-date and performant in the context of the new economy - the knowledge-based economy. 


\section{Corporate Social Responsibility}

Corporate social responsibility represents one of the key concepts and approaches in the management of companies and has a great influence on the treatment of stakeholders. Corporate social responsibility has a long history, starting from the beginning of the nineteenth century, but the major development of the modern corporate social responsibility can be traced back to the 1960s and 1970s (Freeman, Harrison, Wicks, Parmar, \& De Colle, 2010). Corporate social responsibility has been defined and approached in a large variety of ways. According to Wang (2015), it has been grouped into four main categories: corporate social responsibility, corporate social performance, corporate citizenship, and corporate philanthropy.

In the first category - corporate social responsibility - four types of approaches have been identified. The integrative approach is the most widely used and the most important, being based on systemic vision. The other three approaches of corporate social responsibility are oriented toward certain types of problems - economic, voluntary, and public each of them important, but neglecting the other essential aspects of corporate social responsibility.

Carroll's approach, reflected in the pyramid of corporate social responsibilities, is the best-known, most widely disseminated and most frequently used integrative approach of corporate social responsibility. For this reason, we shall present it briefly. Carroll's pyramid, based on his corporate social responsibility definition from 1979, was published in 1991. According to Carroll (1991), corporate social responsibility encompasses the economic, legal, ethical, and discretionary (philanthropic) expectations that society has of organizations at a given point in time. The definition contains a set of four responsibilities, which creates a foundational infrastructure that helps to characterize the nature of a company's responsibilities to the society.

- Economic responsibility is a fundamental condition of businesses' existence that permits them to be created, to survive, and to sustain. Society expects and requires companies to be able to sustain themselves and this is not possible without being profitable. A company needs profit in order to reward the owners and to reinvest for growth, making more products, services, and value added. Economic responsibility is a baseline requirement without which the company cannot exist in a competitive economy;

- Legal responsibilities reflect the society's view of "codified ethics", containing the ground laws and regulations that have to be applied by the company. Laws and regulations incorporate the fundamental notions of fair business practices, and companies must comply with them as a condition of operating in business; 


\section{Stakeholders-Based Management}

- Ethical responsibilities reflect the society's expectations regarding those activities, norms, standards, and practices that companies should respect when they operate and conduct their affairs. Society's ethical requirements are in addition to the laws and regulatory provisions. Ethical responsibilities are a full range of norms, standard, values, principles and expectations of what consumers, the community, company employees, and owners regard as normal in the protection of stakeholders' moral rights;

- Philanthropic responsibilities deal with all forms of company giving, including voluntary and discretionary. Company philanthropic actions do not represent a responsibility in a literal sense. They represent a company's feedback to the public expectation that an organization is a "good citizen". Fulfilment of philanthropic responsibilities involves a variety of giving forms - products and services, donations, gifts of monetary resources, organization employees' voluntarism, etc.

Based on these foundations, Carroll elaborated his pyramid, whose main elements are incorporated in Figure 10.7.

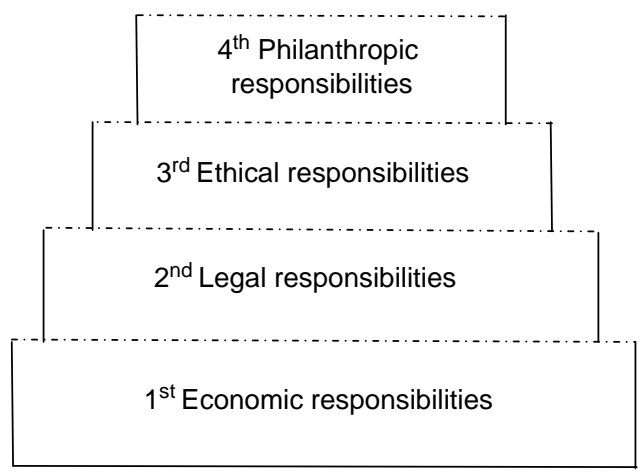

Figure 10.7 Carroll's pyramid of CSR.

Adapted from "The pyramid of corporate social responsibility: Toward the moral management of organizational stakeholders" by A. B. Carroll, 1991, Business Horizons, 34(4), p. 42. Retrieved from https://www.researchgate.net/publication/4883660_The_ Pyramid_of_Corporate_Social_Responsibility_Toward_the_Moral_Management_of_ Organizational_Stakeholders

Later, Archie Carroll made several changes to his corporate social responsibility definition and pyramid (Carroll, 1999; Carroll, 2004; Carroll, 2016), but the most frequently used remain the variants from 1971 and 1991.

Analyses conducted by certain specialists including a comprehensive empirical fundament (Baden, 2016) or in-depth evaluation (Sachs, Rühli, \& Kern, 2009) argued that corporations cannot be seen as purely 
economic entities, detached from individuals. They proposed that corporate social responsibility is "at heart primarily a moral concept designed to highlight the responsibilities of business (as a minimum), to avoid causing harm to society and environment, or, more proactively, contributing to the welfare of society and its stakeholders" (Baden, 2016). Denise Baden proposed a new corporate social responsibility pyramid, whose essential elements are presented in Figure 10.8.

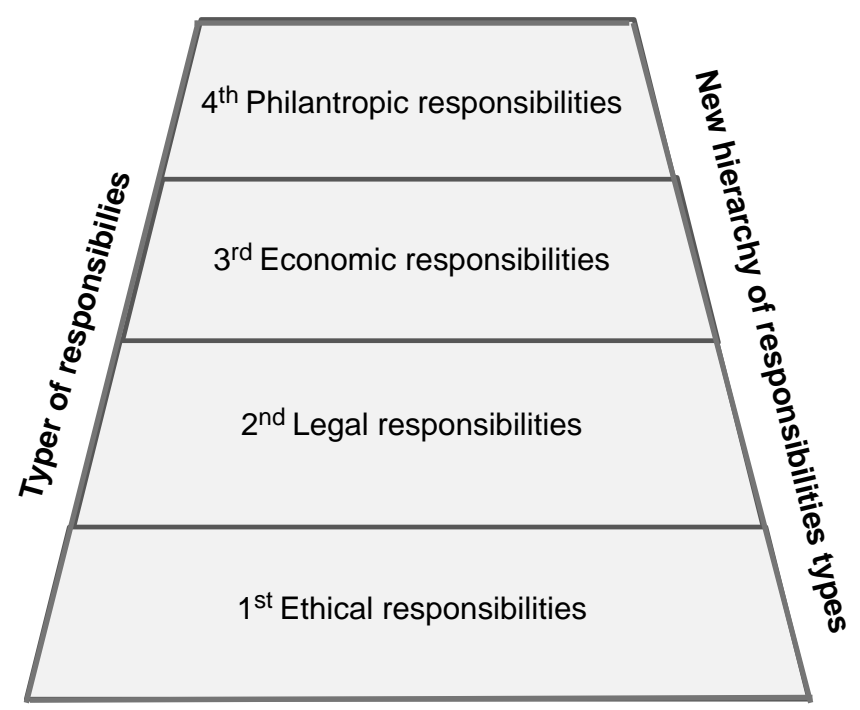

Figure 10.8 Proposed amended pyramid of CSR by Baden.

Adapted from "A reconstruction of Carroll's pyramid of corporate social responsibility for 21st century" by D. Baden, 2016, International Journal of Corporate Social Responsibility, 1(8). Retrieved from https://www.researchgate.net/publication/305801 033_A_reconstruction_of_Carroll\%27s_Pyramid_of_corporate_social_responsibility_for_ the_21st_century.

In her opinion, this pyramid is more powerful and effective, with a new order of the four types of responsibilities. The main pragmatic conclusions are:

a Companies, "in order to have licence to operate and to be trusted with the production and allocation of scarce natural resources and inherently valuable human resources, [need] to first and foremost accept ethical responsibilities to not harm and conform to society's ethic norms and expectations";

b A company "needs to be compliant with legal responsibilities". A company is only free to make profit and pursue its economic objectives once it has accepted its moral and legal responsibilities. 


\section{Stakeholders-Based Management}

During the last few decades, concomitantly with the theoretical developments of corporate social responsibility, in many companies - especially corporations -elements of corporate social responsibilities have been implemented. Specialists' analyses have identified many elements in which significant progress has been made. We mention just a few of these aspects:

- institutionalization of corporate social responsibility using certain social mechanisms (Bice, 2017)

- corporate social responsibility organizational learning employing models (Zadek, 2004)

- evaluation of employers' and employees' contribution to corporate social responsibility, using the responsibility matrix (HaskiLeventhal, Roza, \& Meijs, 2017)

- measuring corporate social responsibility employing a new tool conceived as a superordinate, multidimensional construct (El Akremi, Gond, Swaen, De Roek, \& Igalens, 2018)

- design and use of special indexes for evaluating corporate social responsibility initiatives (Giannarakis, Garefalakis, Lemonakis, \& Konteos, 2017)

- construction of special models to determine the impact of social responsibility investment on a firm's market value (Mackey, Mackey, \& Barney, 2007)

- relationships between intangibles of productivity and corporate social performance (Hasan, Kobeissi, Liu, \& Wang, 2018)

- types of congruence between organizations and their corporate social responsibilities (De Jong \& Van der Meer, 2017)

- use of mediating mechanisms in the relationships between corporate social responsibility and corporate financial performance (Karaye, Ishak, \& Che-Adam, 2014)

- relationships between corporate social responsibility and employee engagement (Flammer \& Luo, 2017; Mirvis, 2012; Rampersad, 2017)

- connection between corporate social responsibility and corporate political responsibilities (Djelic \& Etchanchu, 2017; Lyon et al., 2018; Schrempf-Stirling, Palazzo, \& Phillips, 2016)

- $\quad$ strategic corporate social responsibility (Chandler \& Werther, 2014; Haski-Leventhal, 2018)

This information indicates that the approach of corporate social responsibility is quite comprehensive, dealing with many important elements involved in social corporate responsibility and company management.

Edward Freeman et al. (Freeman et al., 2010) identified in the development of corporate social responsibility from the perspective of stakeholder theory "two distinct lines of thought for the integration of 
financial and social concerns that seem to proceed in parallel and still coexist in ongoing academic research and managerial practice":

a the residual view of corporate social responsibility, which is the initial view on it and is still predominant in theory and practice. The residual view conceptualizes corporate social responsibility as a nonstrategic activity due to the giving back to society some of the value they created, mainly as a moral obligation;

$\mathrm{b}$ the integrative view of corporate social responsibility, which conceptualizes its integration of social, ethical and environmental concerns into management criteria as a strategic activity.

The integrative view refers to a deep change in the approach of corporate social responsibility, taking into consideration the multidimensionality of company stakeholders' management as strategic producers and claimants of value created in the company.

The implementation of corporate social responsibility has generated and this is the predominant specialists' point of view - many positive effects. Specialists from the International Institute for Sustainable Development (2013) elaborated a comprehensive list of corporate social responsibility benefits, structured in three categories:

\section{a Company benefits}

- improved financial performance

- lower operating costs

- enhanced brand image and reputation

- increased sales and customer loyalty

- more ability to attract and retain employees

- reduced regulatory oversight

- access to capital

- workforce diversity

- product safety and decreased liability

b Benefits for the community and the general public

- charitable contributions

- employee volunteer programmes

- corporate involvement in community education, employment and home lesson programmes

- product safety and quality

c Environmental benefits

- greater material recyclability

- better product durability and functionality

- greater use of renewable resources 
- integration of environment management tools into business, including life cycle assessment and costing, environmental management standards and eco-labelling

Despite these benefits, certain reputed specialists assert, based on comprehensive analysis, that corporate social responsibility remains a controversial topic (Chandler \& Werther, 2014).

\section{Company-Relevant Stakeholder Responsibilities}

The formulation and the idea of "company stakeholders' responsibilities" has been very well argued and promoted by renowned specialists Freeman, Harrison, Wicks, Parmar, and De Colle (2010). They proposed "[replacing] corporate social responsibility" with company stakeholders' responsibilities. According to them, a "company signals all forms of value creation and trade, all business and non-profit organizations". Their main arguments are the following:

- responsibilities are not contingent on the size and success of one type of organization; all companies should shoulder responsibilities;

- the main goal of corporate social responsibility is to create value for key stakeholders - not only for shareholders - and to fulfil the responsibilities to them;

- company responsibilities imply that we cannot separate business from ethics, because business, ethics, and societal considerations are interdependent and should be integrated.

Based on these arguments, they state that

company stakeholder responsibility looks at business and society as intertwined, it looks not just at corporations, but at many forms of organizations and promotes a pragmatic view on managing relationships with all the organization's stakeholders, as a primary task toward success (Freeman et al., 2010).

Recently, continuing this approach, Freeman and Elms (2018) argued: "The social responsibility of business is to create value for stakeholders. That means its customers, suppliers, employees and communities, as well as its shareholders".

Business realities provide other pragmatic elements for the reconsideration of corporate social responsibility. We shall highlight some of them:

- social corporate responsibility is implemented to different extents in a small number of corporations, especially from Great Britain, the United States, Canada, and a few other developed countries; 
- in the use of corporate social responsibility in corporations, frequently not all major elements incorporated by the corporate social responsibility concept are practised (Baden, 2016; Carroll, 2004; Djelic \& Etchanchu, 2017; Mirvis, 2012; Rampersad, 2017; Wang, 2015; Zadek, 2004);

- the corporation culture does not usually incorporate corporate social responsibility as a major element;

- in the training and development of managers and other human resources, the topic of corporate social responsibility is not included, or only as a peripheral subject;

- many major stakeholders are not taken into consideration in companies where corporate social responsibility is used;

- the present corporate social responsibility approaches in companies are focused more on the processes involved and less on the stakeholders, on the people, structures or organizations that in practice make/perform the necessary decisions, actions, and behaviours.

The new approach of social responsibility in companies should be holistic in all respects - objectives, responsibilities, organizations, stakeholders, and managerial mechanisms.

We propose, based on the previous elements and other analyses, a variant of new holistic organization responsibilities, called "company stakeholders relevant responsibilities", which has the following features:

a Responsibility includes all types of social responsibilities, with the condition that they must be relevant. This means that we propose a new concept of relevant responsibility. A company responsibility is a relevant responsibility if it respect the criteria incorporated in Table 10.2.

b Company-relevant responsibility deals with every company-relevant stakeholder.

c Company-relevant responsibilities are correlated with multiobjectives of the company and its relevant stakeholders.

d Company-relevant responsibilities take into consideration the relevant responsibilities according to their characteristics and not occasionally, when a crisis occurs, when there is major pressure from powerful relevant stakeholders, etc.

e Different types of responsibilities are correlated taking into consideration their multidimensional nature, and the company and the relevant stakeholders' multi objectives.

f Relevant responsibilities should be reflected in the relevant organizational and individual stakeholders' objectives, roles, tasks, competencies, and responsibilities.

g Relevant responsibilities should be taken into consideration and 
Table 10.2 Criteria (requirements) for company-relevant responsibility

\begin{tabular}{cl}
\hline No. & Relevance Criteria \\
\hline $1 . \quad \begin{array}{l}\text { Responsibility refers to a major "social" need of the society, company } \\
\text { and/or the relevant stakeholder }\end{array}$ \\
2. \\
$\begin{array}{l}\text { Responsibility could be economic, social, legal, moral, or ecologic } \\
\text { order to ensure relationship continuity and stability between the } \\
\text { company and relevant stakeholders }\end{array}$ \\
$\begin{array}{l}\text { Responsibility accomplishment involves, from the company and the } \\
\text { relevant stakeholders, specific decisions, actions and behaviours, } \\
\text { which consume substantial time, knowledge and other resources } \\
\text { Responsibility has - after fulfilment - a significant positive impact on } \\
\text { major elements regarding company and/or relevant stakeholders: } \\
\text { organizational performance, individual performance, degree of } \\
\text { motivation of the individuals involved, environment protection, social } \\
\text { welfare, education, poverty, intellectual capital protection and } \\
\text { valorification, prestige and reputation of the organizations, and } \\
\text { individual stakeholders involved and others } \\
\text { Responsibility fulfilment contributes significantly to the sustainability of } \\
\text { the company and of the relationships between organization and } \\
\text { relevant stakeholder, by taking into consideration some grand societal } \\
\text { challenges }\end{array}$ \\
6.
\end{tabular}

implemented in all types of companies, regardless of their characteristics (size, profile, performance, location, etc.), because the content of the responsibilities reflects the major interests, objectives, and necessities of the society, economy, and population.

h Relevant responsibilities should be approached and implemented bearing in mind the particularities of each company (size, profile, age, technological level, organizational culture, performances, etc.) and of each relevant individual and organizational stakeholder.

i Company-relevant responsibilities should be realistic and equilibrated, at least in two area:

- the reasonable fulfilment of the relevant responsibilities of the company and the relevant stakeholders

- the enabling of the company and relevant stakeholders' sustainability

In Table 10.3, we have synthesized the main differences between corporate social responsibilities and the company-relevant stakeholders' responsibilities.

All the above elements represent reasons for us to propose an alternative to the Carroll pyramid or to other pyramids (see, e.g., Baden, 2016) of corporate social responsibilities - the responsibilities relevant pentagon of the company (Figure 10.9). 
Table 10.3 The main differences between corporate social responsibilities and company-relevant stakeholders' responsibilities

\begin{tabular}{|c|c|c|c|}
\hline No. & Elements & $\begin{array}{l}\text { Corporate Social } \\
\text { Responsibilities }\end{array}$ & $\begin{array}{l}\text { Company-Relevant } \\
\text { Stakeholders' } \\
\text { Responsibilities }\end{array}$ \\
\hline 1. & Type of organization & Corporation & All types of organization \\
\hline 2. & Type of responsibility & Social responsibility & $\begin{array}{l}\text { All types of relevant } \\
\text { responsibilities }\end{array}$ \\
\hline 3. & $\begin{array}{l}\text { Type of stakeholders } \\
\text { taken into } \\
\text { consideration }\end{array}$ & $\begin{array}{l}\text { Certain primary } \\
\text { corporation } \\
\text { stakeholders }\end{array}$ & $\begin{array}{l}\text { All relevant company } \\
\text { stakeholders }\end{array}$ \\
\hline 4. & Business objectives & $\begin{array}{l}\text { Mainly to create value } \\
\text { for company }\end{array}$ & $\begin{array}{l}\text { To create value for } \\
\text { company and company- } \\
\text { relevant stakeholders }\end{array}$ \\
\hline 5. & $\begin{array}{l}\text { Responsibilities to be } \\
\text { fulfilled }\end{array}$ & $\begin{array}{l}\text { Take care of some } \\
\text { social responsibilities } \\
\text { toward certain } \\
\text { stakeholders }\end{array}$ & $\begin{array}{l}\text { All relevant organization } \\
\text { responsibilities to all } \\
\text { relevant stakeholders }\end{array}$ \\
\hline
\end{tabular}

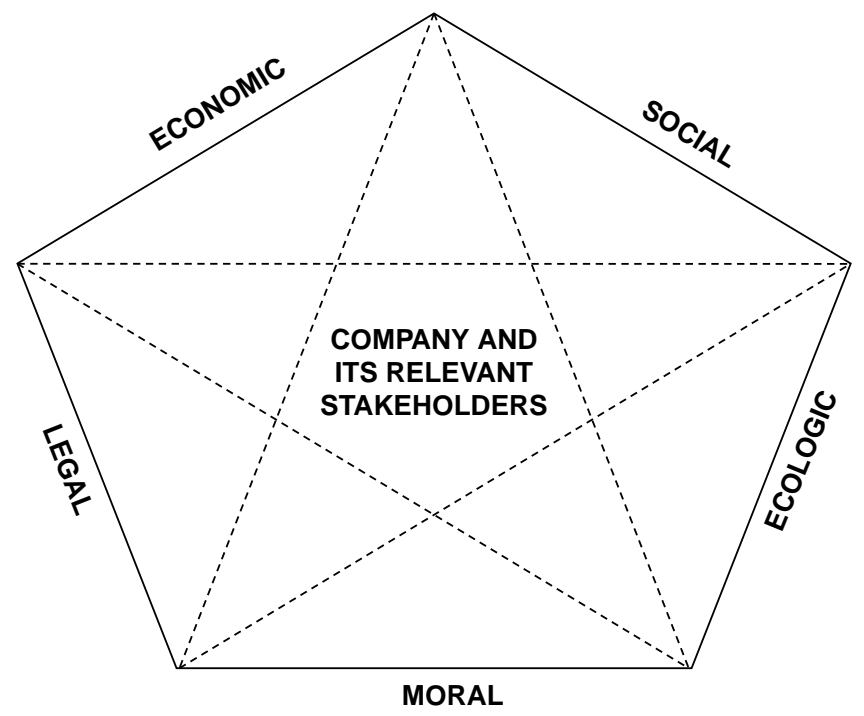

Figure 10.9 Pentagon of company-relevant stakeholders' responsibilities.

Compared with the previous responsibilities pyramids, a companyrelevant responsibilities pentagon presents certain specific features:

1 It is focused on the company, its relevant stakeholders and relevant responsibilities; 
2 It eliminates the mechanical separation and the hierarchical ordination of the different types of social responsibilities;

3 The relevant ecologic responsibilities have been introduced, taking into consideration the recent evolution in the world economy and society, and in science;

4 It is based on the holistic approach taking into consideration all main faces of the relevant responsibility in their systemic interdependences, connected to the company and its relevant stakeholders.

The pentagon of the company-relevant responsibilities represents a good background for a more comprehensive and pragmatic approach in contemporary companies and their environment and for taking into consideration the present and future grand societal challenges. In order to fully achieve this, new systemic management mechanisms are necessary that are able to incorporate and fulfil the organizational and individual objectives, decisions, actions and behaviours, etc. involved in the five types of relevant responsibilities, according to the necessities and expectations of the company and relevant stakeholders, internal and external. A company-relevant stakeholder-based management system could be such a managerial mechanism, because through its design and characteristics it is focused on the company and its relevant stakeholders in a holistic and sustainable manner.

Use of the company-relevant stakeholders-based management system, integrating the company-relevant responsibilities, has multiple advantages:

a It integrates and operates all types of relevant responsibilities of the company and relevant stakeholders;

b Relevant company responsibilities are permanently approached and implemented based on the specific economic, social, legal, ecologic, and moral criteria, rationally and coherently defined and correlated;

c It is able to operate a proactive approach to company-relevant responsibilities, preventing a crisis and highly tensioned situations at the company and relevant stakeholders level;

d It uses win-win negotiation, reciprocal behaviour and other specific elements of the stakeholders-based management system in the defining and taking into consideration of the relevant company responsibilities, which determine realistic approach and implementation;

e All the above-mentioned elements generate a sustainable implementation and development of the relevant responsibilities at the level of company-relevant stakeholders.

Company-relevant stakeholders' responsibilities overcome corporate social responsibility, having great potential for increasing multidimensional 
performances at the level of companies, stakeholders, the economy and the entire society. This represents one step ahead in the development of an integrative view of corporate social responsibilities and could be very useful in the context of the pandemic and post-pandemic COVID-19.

\section{Development and Implication of Humanistic Management in Companies}

All economic, social or managerial entities or processes are designed, implemented and developed by individuals, such as entrepreneurs, managers, shareholders, executants, etc. For this reason, the interest, native quality, competence, information, knowledge, culture and other characteristics of the people participating in the work processes are essential. The existence, characteristics, and performances of any business, social, or ecologic processes are decisively influenced by the individuals involved.

In the present context of the transition to a knowledge-based economy, of the fast digital transformation, the impact of individuals and groups of people on each activity and in every field has increased, becoming determinant because of their knowledge, of their intellectual capital, which are the vectors of development in all organizations.

In the last few decades, the awareness of the huge role and influence of the individual and the society has rapidly increased, in the context of the continuous increase of people's education level and skills, and the demonstration of the efficiency relationship between the quality of human resources and the entity functionality and performance. We can see this awareness in many fields - science, education, health, economy, etc. In the management of a company this evolution determines that human resources become a central part of it. In Table 10.4, we present some significant elements showing these mutations.

Humanistic management means more than the reconsideration of human resource management. According to certain specialists (e.g. Dierksmeier, 2016), all humanistic management advocates a paradigm shift in business theory as well as in management practice. In the field of theory, they suggest a transition from mechanistic economics towards humanistic economics, so as to move in practice away "from capitalistic" to "humanistic business". Humanistic management specialists endorse and affirm the centrality of human rights for all forms and aspects of management (Dierksmeier, 2016). Humanistic management aims to create a more balanced relationship between those things that can be exchanged on markets and those that cannot, but that make life worthwhile, like human dignity and well-being (Pirson, 2017).

Humanistic management involves many changes in organization management, such as: redesigning the company into a vehicle for cultivation of 
Table 10.4 Main elements of the company human resource reconsideration

No. Elements

1. Human resource is considered and treated as an essential company resource

2. Human resource management has developed rapidly, as a main company function or field, integrating - especially in corporations and large companies - many specialized activities: planning, selection, integration, evaluation, training, motivation, protection, and others

3. Reconsideration of the company employee, being more frequently treated as having a personality with multifaceted dimensions, needs to be taken into consideration in the organization and its management

4. Company human resource strategy and policies become more frequent and more influential on the organization's work and performance

5. Many managerial systems, methods and techniques focused on human resources - like participative management systems and approaches, teamwork, dialogic communication, $360^{\circ}$ evaluation, personality texts, management simulation, etc. - have been developed

6. Continuous and intensive training of company employees inside and outside the organization

7. Ascension of leadership, including collective leadership, concentrated on communication, implication, and engagement of the company human resource

8. Organizational and individual culture of the employees in companies tend to become more open, collaborative, and integrative, paying great attention to human resource characteristics

the humanistic relationships inside and outside the organization; promoting self-management-oriented leadership styles; supporting a transformational company culture; avoiding control mechanisms obstructing creativity and initiative; promoting democratic dialogue-based processes and participative management; developing dignity in the workplace in a procedural and participative approach; and transforming human value and virtue in essential components of the organization management (Dierksmeier et al., 2011; Pirson, 2017; Von Kimakowitz, Pirson, Spitzeck, Dierksmeier, \& Amann, 2011).

Within humanistic management, special attention is paid to stakeholders. Humanistic management aims to honour the freedom of each business stakeholder, by involving them, as much as possible, in making those decisions that impact their lives. Ideally, everyone who is affected by management should be able to have an effect on it, wherever possible directly, and where impossible, indirectly, by way of representation (Dierksmeier, 2016). Recently, almost 200 CEOs under auspices of the International Council for Small Business (ICSB) (2019) proposed a Human Entrepreneurship Framework within which they share a fundamental commitment to all stakeholders to deliver value to all of them for the future success of companies, communities and countries. 
Humanistic management, according to some specialists (e.g. Dierksmeier, 2016; Dierksmeier et al., 2011; Pirson, 2017; Von Kimakowitz et al., 2011), generates multiple advantages (see Figure 10.10).

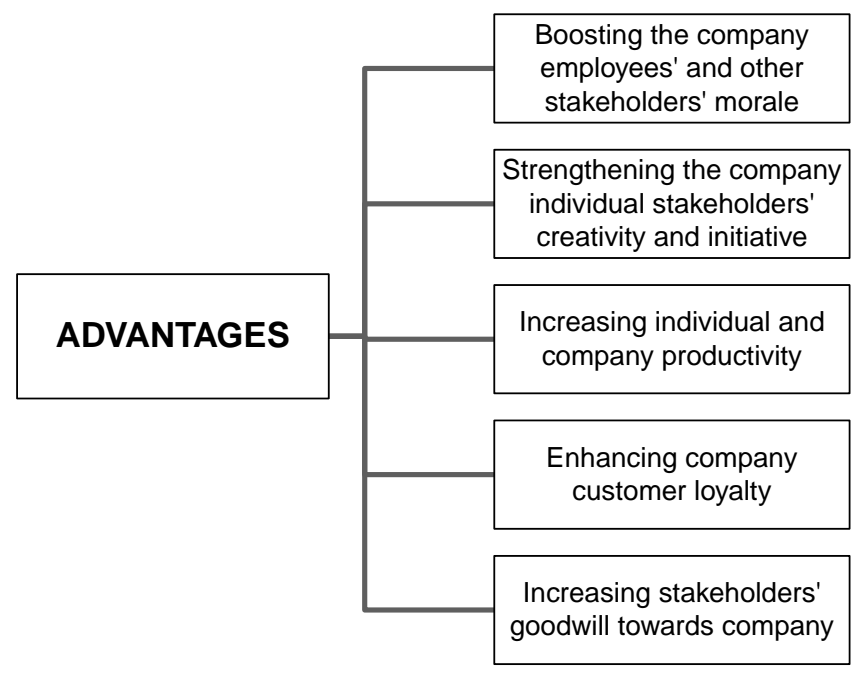

Figure 10.10 Main advantages of implementing humanistic management.

Despite these essential advantages, humanistic management is implemented only to a low extent in companies and, frequently, only in some components that are able to improve certain elements of the organization's activities. Implementation of humanistic management needs radical transformation in the company and its management, which is very complex and difficult to do. In our opinion, managerial synapses and a company-relevant stakeholders-based management system are able to do this. Their nature and main characteristics are fully compatible with humanistic management's aims and means. Integration of the humanistic management vision, which is very helpful in the pandemic context, into the relevant stakeholders-based management system will enhance the work and the performance of the company, concomitantly with the generation of much more satisfaction and many more implications for, and accomplishments by, individual internal and external stakeholders.

\section{Emotions and Emotional Intelligence in Companies}

The psychological foundation of the company-relevant stakeholders-based management system is represented by new approaches to people emotions and emotional intelligence in the organization. The study of emotions and affect in organizations started over 20 years ago, revealing their numerous 
influences on the work of people and on the activities in the company. The prestigious scientific publication Academy of Management Review focused a special issue ${ }^{3}$ on this subject, publishing eight studies and proposing a new theory regarding emotion in management (Ashkanasy, Humphrey, \& Huy, 2017).

The new science of emotion contributes to generating practical techniques for helping organizations to enhance their sensing, seizing and transforming capabilities (Forgas, 2000). Researches by Professor Forgas (2008) and Healey and Hodgkinson (2017) demonstrated that the following these are essential for people's work and performances in an organization:

- affect and cognition are not separate - thought and emotion are intertwined;

- feelings have a multifaceted influence on everything that we think or do;

- mood affects memory and critical thinking.

From the company management point of view, it is essential to understand the emotions of employees and other stakeholders and to regulate their effects. A very useful tool for doing this is the model of emotions known as the "affective circumplex", proposed by Healey and Hodgkinson. They take into consideration a large number of people's emotions - 16 - most frequently encountered in an organization. People's emotions are organized in a circular structure, focused on two major dimensions:

- the first category reflects the degree of energy evoked by particular emotions, which can vary between low and high;

- the second category differentiates emotions in terms of their degree of pleasantness, which can vary between pleasant and unpleasant.

The value of this model consists in providing a comprehensive picture of the main emotions of the people in an organization and of their significance in terms of the energy involved and the pleasantness associated with each of them. Based on these elements their effects, positive or negative, in the organization have been established along with the type of feedback necessary from company managers. The circumplex model of affect helps company managers to regulate the control of emotions, which means what emotions are experienced, when they are experienced and how they are experienced and used. Emotion regulation is closely related to people's capabilities of self-control and willpower (Forgas, 2000; Healey \& Hodgkinson, 2017) and help managers in managing the emotional dynamics of transformation in the company. Emotion regulation helps organization managers to increase their sensing, seizing and transforming capabilities at the level of workplaces, departments, and entire organizations. 
Emotion regulation is very important because of the major influence of emotions on the decisions, actions and behaviours of all managers, executants or other stakeholders. Company components and, generally, people do not make decisions based on fact, information, and knowledge alone. Their emotions contribute substantially to what decisions they make, how they implement them and the results generated. For this reason, company managers should have emotional competences, which refers to the ability to experience and display emotions that are deemed appropriate for an actor role in an institutional order (Voronov \& Weber, 2015). Emotional competence depends decisively on the emotional intelligence of a person. Emotional intelligence involves four main processes:

- emotion identification

- emotion understanding

- emotion regulation

- emotion use

Emotional intelligence is based on specific competencies. In a recent study, the emotional intelligence competencies (McKee, 2017) regarding self-awareness, social awareness, self-management and relationship management, have been recommended to be used in the company management.

Managers having and using these emotional competencies determine the development of the healthy emotional climate in the company, which is always an affective climate enabling organizational effectiveness (Ashkanasy et al., 2017). The use of emotional intelligence in a company is not limited to the manager-subordinate relationship. It can also be used in relationships with other internal and external stakeholders. The more you are aware of and understand stakeholders' emotions, the greater the influence you can have (Green, 2015). In approaching a stakeholder, specialists recommend preparing and utilizing an emotional profile. So far, this has been used in particular in relationships with major stakeholders within the management of important projects. Our opinion is that the elaboration and use of an emotional profile is recommended in the relationship with each new relevant company stakeholder. In this process, two emotional intelligence skills are essential for company managers:

- emotional awareness of others; this means the capacity to read relevant stakeholders' emotions in advance of working with them;

- managing others' emotions, which means the capacity to effectively manage stakeholders' emotions in the work processes fulfilled together. 


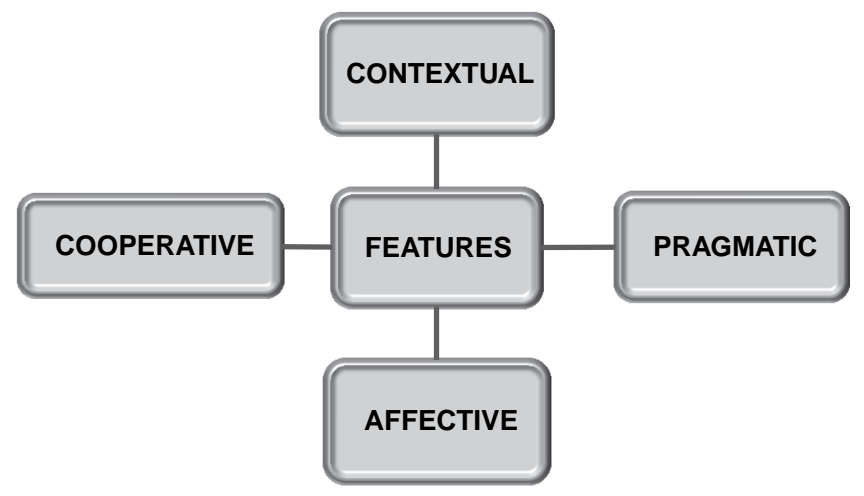

Figure 10.11 Emotional intelligence features, enabling new types of relationship with relevant company stakeholders.

We believe that emotional intelligence has four features that make it essential in the new management approach to the relationships with relevant company stakeholders (see Figure 10.11).

a Emotional intelligence is contextual; it allows the company manager and other stakeholders too - to perceive, interpret and act taking into consideration the major elements around them in their work and life area. This helps the stakeholder to be open to the specificity of the management synapse, to the common objectives, win-win negotiation, intense communication and consultation, and reciprocity. This contributes to the construction of an enabling emotional climate for the stakeholders' relationships;

b Emotional intelligence is pragmatic in the sense that it helps stakeholders, based on the contextual approach, to see and to understand the positive and negative impacts of the different components of their workspace and life space and to generate useful and protective feedback;

c Emotional intelligence is affective because it mobilizes stakeholders' affective resources, their feelings, which have the capacity to increase motivation, involvement and engagement, in order to achieve what is necessary and to solve the problems at the workplace and in the company too. The affective dimension of emotional intelligence is a very good psychological support in order to construct performant synapses and to develop a stakeholders-based management system;

$\mathrm{d}$ Emotional intelligence has a cooperative dimension based on contextual, pragmatic and affective features, because it helps to generate stakeholders' desire and the openness that enables the individual to have contacts, to communicate and to work with other people, to cooperate with them. Emotional intelligence, more than intellectual 
intelligence, helps one to have successful win-win negotiations, to achieve reasonable compromises, to work better together within the stakeholders-based management system.

Elements regarding people's emotions, emotion regulation, emotional intelligence, etc. constitute valuable psychological arguments for the stakeholders-based management construction and development.

\section{New Company-Relevant Stakeholders' Business Model Framework}

Every company and management system should be based on a business model that synthesizes the economic background of the entity and design logic of the essential business and management processes and relationships to be achieved in order to be performant. We have elaborated for company stakeholders-based management a new type of business model that is radically different from classical business models (see Figure 10.12).

Examination of a large number of classical business models and their characteristics and approaches (Bodrožić \& Adler, 2018; Casadesus-Masanell \& Zhu, 2013; Chesbrough, 2010; Demil, Lecocq, Ricart, \& Zott, 2015; Garcia-Castro, Ricart, Lieberman, \& Balasubramanian, 2017; Green, 2015; Kortmann \& Piller, 2016; Laasch, 2018; Zott \& Amit, 2010) has revealed the following common features:

- they are focused on profit generation and capture by company shareholders;

- they usually take into consideration only one external stakeholder the client;

- they treat the client not as an organization stakeholder but as an essential constituent of the market, who should be convinced to buy company products and services;

- they neglect, to a large extent, the social, ecological, and psychological implications of company activities.

The relevant stakeholders' approach involves other types of business models. In Figure 10.12 we present the main elements of a companyrelevant "stakeholders' business model framework", which has as its strategic objective the achievement of the organization's sustainability, valorizing the relevant internal and external stakeholders' resources and potential. The main characteristics of the company-relevant stakeholders' company business model, which makes it different from the classical business model, are the following:

- It is based on the relevant internal and external company stakeholders, integrated into the global network; 

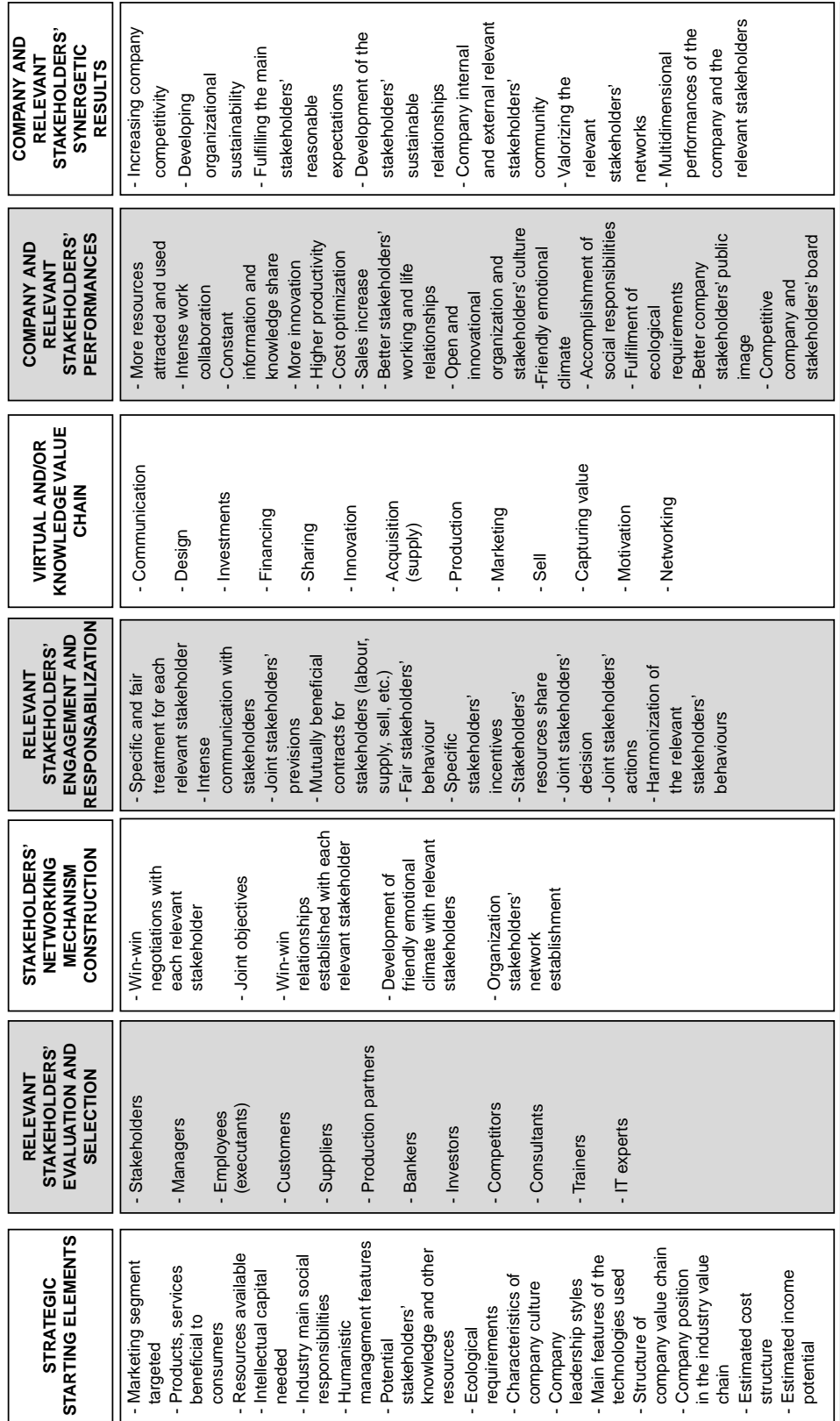
- It is based on the virtual and knowledge value chain of the organization;

- It takes into consideration a joint relevant stakeholders' generation and capture of value;

- It integrates the company-relevant stakeholders' responsibilities;

- It incorporates essential elements of humanistic management and emotional intelligence;

- It is conceived and operated based on the stakeholders' win-win negotiations and sustainable relationships;

- It is focused on the sustainable development of a stakeholders' network, centred on the organization;

- It generates sustainable multidimensional performances for the company and its relevant stakeholders.

In order to be operational and to generate performance, the companyrelevant stakeholders' business model framework should be concretized at the level of each entity, taking into consideration the particularities of the organization, its relevant stakeholders and the environment involved.

The relevant stakeholders business model provides the background for construction and implementation of the company-relevant stakeholdersbased management system. The company-relevant stakeholders' business model projected by us is only one variant of the new type of business model. It is always possible to conceive other variants starting from other premises and/or following a different approach.

Without any doubt, in these very complex and fast contextual changes and challenges generated by the transition to the knowledge-based economy, the fast digital transformations and other political, social, ecological, etc. mutations - including those generated by the COVID-19 pandemic - company management should be radically updated, indeed reinvented. Our proposals represent just an attempt to contribute to the development of the new type of management needed and demanded by companies today.

\section{Notes}

1 We use for the new necessities and approaches regarding the company employees as individual persons, the concept "humanistic approach", which incorporates quite a few innovational elements [see Pirson, M. (2017). Humanistic management: Protecting dignity and promoting well-being. Cambridge, UK: Cambridge University Press. doi:10.1017/9781316675946; Dierksmeier, C. (2016). What is 'humanistic' about humanistic management? Humanistic Management Journal, 1, 9-32. doi:10.1007/s41463-016-0002-6; Von Kimakowitz, E., Pirson, M., Spitzeck, H., Dierksmeier, C., \& Amann, W. (Eds.) (2011). Humanistic management in practice. Basingstoke, UK: Palgrave Macmillan]. We mention the emotional intelligence separately because although it is involved in humanistic management, it has major influence on the other parts of company management. Emotional intelligence decisively affects 
the approach of the company stakeholders - both internal and external deserving a special treatment and needing new management mechanisms in order to fully valorized it.

2 See Journal of Management Studies (2015), 52(7). doi:10.1111/joms.12153

3 We refer to the volume 42, issue 2, 2017 of the Academy of Management Review.

\section{References}

Amit, R., \& Zott, C. (2001). Value creation in e-business. Strategic Management Journal, 22(6-7), 493-520. doi:10.1002/smj.187

Ashkanasy, M., Humphrey, R. H., \& Huy, Q. N. (2017). Integrating emotions and affect in theories of management. Academy of Management Review, 42(2), 175-189. doi:10.5465/amr.2016.0474

Baden, D. (2016). A reconstruction of Carroll's pyramid of corporate social responsibility for 21st century. International Journal of Corporate Social Responsibility, 1(8), 1-15. Retrieved from https://www.researchgate.net/ publication/305801033_A_reconstruction_of_Carroll\%27s_Pyramid_of_corporate_social_responsibility_for_the_21st_century 10.1186/s40991-016-0008-2

Bice, S. (2017). Corporate social responsibility as institution: A social mechanisms framework. Journal of Business Ethics, 143(1), 17-34. doi:10.1007/s1 0551-015-2791-1

Bodrožić, Z., \& Adler, P. S. (2018). The evolution of management models: A neo-schumpeterian theory. Administrative Science Quarterly, 63(1), 85-129. doi: $10.1177 / 0001839217704811$

Bosse, D. A., Phillips, R.A., \& Harrison, J. S. (2009). Stakeholders, reciprocity, and firm performance. Strategic Management Journal, 30(4), 447-456. doi:10.1002/smj.743

Bowman, C., \& Ambrosini, V. (2000). Value creation versus value capture: Towards a coherent definition of value in strategy. British Journal of Management, 11(1), 1-15. doi:10.1111/1467-8551.00147

Brandenburger, A. M., \& Stuart Jr., H. W. (1996). Value-based business strategy. Journal of Economics \& Management Strategy, 5(1), 5-24. doi:1 0.1111/j.1430-9134.1996.00005.x

Carroll, A. B. (1991). The pyramid of corporate social responsibility: Toward the moral management of organizational stakeholders. Business Horizons, 34(4), 39-48. Retrieved from https://www.researchgate.net/publication/4883660_The_ Pyramid_of_Corporate_Social_Responsibility_Toward_the_Moral_Management_ of_Organizational_Stakeholders 10.1016/0007-6813(91)90005-G

Carroll, A. B. (1999). Corporate social responsibility: Evolution of a definitional construct. Business \& Society, 38(3), 268-295. doi:10.1177/000765039903 800303

Carroll, A. B. (2004). Managing ethically with global stakeholders: A present and future challenge. Academy of Management Perspectives, 18(2), 114-120. doi: 10.5465/ame.2004.13836269

Carroll, A. B. (2016). Carroll's pyramid of CSR: Taking another look. International Journal of Corporate Social Responsibility, 1(3), 1-8. doi:10.11 86/s40991-016-0004-6 
Casadesus-Masanell, R., \& Zhu, F. (2013). Business model innovation and competitive imitation: The case of sponsor-based business models. Strategic Management Journal, 34(4), 464-482. doi:10.1002/smj.2022

Chandler, D., \& Werther, B. W. (2014). Strategic corporate social responsibility: Stakeholders, globalization and sustainable value creation (3rd ed.). Los Angeles, CA: Sage Publications.

Chesbrough, H. (2010). Business model innovation: Opportunities and barriers. Long Range Planning, 43(2-3), 354-363. doi:10.1016/j.lrp.2009.07.010

Choi, J., \& Wang, H. (2009). Stakeholder relations and the persistence of corporate financial performance. Strategic Management Journal, 30(8), 895-907. doi: $10.1002 / \mathrm{smj} .759$

De Jong, M. D. T., \& Van der Meer, M. (2017). How does it fit? Exploring the congruence between organizations and their corporate social responsibility (CSR) activities. Journal of Business Ethics, 143(1), 71-83. doi:10.1007/s1 0551-015-2782-2

Demil, B., Lecocq, X., Ricart, J. E., \& Zott, C. (2015). Introduction to the SEJ special issue on business models: Business models within the domain of strategic entrepreneurship. Strategic Entrepreneurship Journal, 9(1), 1-11. doi:10.1002/sej.1194

Dierksmeier, C. (2016). What is "humanistic" about humanistic management? Humanistic Management Journal, 1, 9-32. doi:10.1007/s41463-0160002-6

Dierksmeier, C., Amann, W., Kimakowitz, E.V., Spitzeck, H., Pirson, M., Von Kimakowitz, E. (Eds.) (2011). Humanistic ethics in the age of Globality. Basingstoke, UK: Palgrave Macmillan. doi:10.1057/9780230314139

Djelic, M.-L., \& Etchanchu, H. (2017). Contextualizing corporate political responsibilities: Neoliberal CSR in historical perspective. Journal of Business Ethics, 142(4), 641-661. doi:10.1007/s10551-015-2879-7

Dorobantu, S., \& Odziemkowska, K. (2017). Valuing stakeholder governance: Property rights, community mobilization, and firm value. Strategic Management Journal, 38(13), 2682-2703. doi:10.1002/smj.2675

El Akremi, A., Gond, J.-P., Swaen, V., De Roek, K., \& Igalens, J. (2018). How do employees perceive corporate responsibility? Development and validation of a multidimensional corporate stakeholder responsibility scale. Journal of Management, 44(2), 619-657. doi:10.1177/0149206315569311

Ermine, J.-L. (2013). A knowledge value chain for knowledge management. Journal of Knowledge \& Communication Management, 3(2), 85-101. doi:1 0.5958/j.2277-7946.3.2.008

Flammer, C., \& Luo, J. (2017). Corporate social responsibility as an employee governance tool: Evidence from a quasi-experiment. Strategic Management Journal, 38(2), 163-183. doi:10.1002/smj.2492

Forgas, J. P. (2000). Feeling and thinking: The role of affect in social cognition. Cambridge, UK: Cambridge University Press.

Forgas, J. P. (2008). Affect, cognition, and social behavior: The effects of mood on memory, social judgments, and social interaction. In M. A. Gluck, J. R. Anderson, \& S. M. Kosslyn (Eds.), Memory and mind: A festschrift for Gordon H. Bower (pp. 261-279). New York: Lawrence Erlbaum Associates Publishers. 


\section{Stakeholders-Based Management}

Freeman, E., \& Liedtka, J. (1997). Stakeholder capitalism and the value chain. European Management Journal, 15(3), 286-296. doi:10.1016/S0263-2373 (97)00008-X

Freeman, R. E., \& Elms, H. (2018). The social responsibility of business is to create value for stakeholders. MIT Sloan Management Review. Retrieved from https://sloanreview.mit.edu/article/the-social-responsibility-of-business-is-tocreate-value-for-stakeholders/

Freeman, R. E., Harrison, J. S., Wicks, A. C., Parmar, B. L., \& De Colle, S. (2010). Stakeholder theory: The state of art. New York: Cambridge University Press.

Garcia-Castro, R., \& Aguilera, R. V. (2015). Incremental value creation and appropriation in a world with multiple stakeholders. Strategic Management Journal, 36(1), 137-147. doi:10.1002/smj.2241

Garcia-Castro, R., Ricart, J. E., Lieberman, M. B., \& Balasubramanian N. (2017). Business model innovation and replication: Implications for the measurement of productivity. In E. Grifell-Tatjé, C. A. K. Lovell, \& R. C. Sickles (Eds.), The Oxford handbook of productivity analysis (pp. 359-385). New York: Oxford University Press. doi:10.1093/oxfordhb/978019022671 8.013.10

Giannarakis, G., Garefalakis, A., Lemonakis, C., \& Konteos, G. (2017). The drivers of social responsible stock index: The case of Dow Jones sustainability index world. Corporate Ownership \& Control, 14(2-1), 173-180. doi:10.224 95/cocv14i2c1p3

Green, R. (2015). Do stakeholder's emotions matter? Retrieved from http:// www.theeiinstitute.com/emotional-intelligence-leaders/6-do-stakeholdersemotions-matter.html

Harrison, J. S., \& Wicks, A. C. (2013). Stakeholder theory, value and firm performance. Business Ethics Quarterly, 23(1), 97-124. doi:10.5840/beq2 0132314

Harrison, J. S., Bosse, D. A., \& Phillips, R.A. (2010). Managing for stakeholders, stakeholder utility functions and competitive advantage. Strategic Management Journal, 31(1), 58-74. doi:10.1002/smj.801

Hasan, I., Kobeissi, N., Liu, L., \& Wang, H. (2018). Corporate social responsibility and firm financial performance: The mediating role of productivity. Journal of Business Ethics, 149(3), 671-688. doi:10.1007/s10551-0163066-1

Haski-Leventhal, D. (2018). Strategic corporate social responsibility: Tools and theories for responsible management (1st ed.). London, UK: Sage Publications.

Haski-Leventhal, D., Roza, L., \& Meijs, L. C. P. M. (2017). Congruence in corporate social responsibility: Connecting the identity and behavior of employers and employees. Journal of Business Ethics, 143(1), 35-51. doi:10.1 007/s10551-015-2793-z

Healey, M. P., \& Hodgkinson, G. P. (2017). Making strategy hot. California Management Review, 59(3), 109-134. doi:10.1177/0008125617712258

Hillman, A. J., \& Keim, G. D. (2001). Shareholder value, stakeholder management, and social issues: What's the bottom line? Strategic Management Journal, 22(2), 125-139. Retrieved from https://www.jstor.org/stable/3 094310 
Holsapple, C. W., \& Singh, M. (2001). Knowledge chain model: Activities for competitiveness. Expert Systems with Applications, 20(1), 77-98. doi: 10.1016/S0957-4174(00)00050-6

Holsapple, C. W., \& Jones, K. (2004). Exploring primary activities of the knowledge chain. Knowledge and Process Management: The Journal of Corporate Transformation, 11(3), 155-174. doi:10.1002/kpm.200

ICSB. (2019, August 20). ICSB's humane entrepreneurship initiative adopted by CEOs of nearly 200 companies. Retrieved from https://icsb.org/200ceos/

International Institute for Sustainable Development. (2013). Corporate social responsibility (CSR). Retrieved from https://www.iisd.org/business/issues/ sr.aspx

Karaye, Y. I., Ishak, Z., \& Che-Adam, N. (2014). The mediating effect of stakeholder influence capacity on the relationship between corporate social responsibility and corporate financial performance. Procedia-Social and Behavioral Sciences, 164, 528-534. doi:10.1016/j.sbspro.2014.11.142

Kortmann, S., \& Piller, F. (2016). Open business models and closed-loop value chains: Redefining the firm-consumer relationship. California Management Review, 58(3), 88-108. doi:10.1525/cmr.2016.58.3.88

Laasch, O. (2018). Beyond the purely commercial business model: Organizational value logics and the heterogeneity of sustainability business models. Long Range Planning, 50(1), 158-183. doi:10.1016/j.lrp.2017.09.002

Lee, C. C., \& Yang, J. (2000). Knowledge value chain. Journal of Management Development, 19(9), 783-794. doi:10.1108/02621710010378228

Lepak, D. P., Smith, K. G., \& Taylor, M. S. (2007). Value creation and value capture: A multilevel perspective. Academy of Management Review, 32(1), 180-194. doi:10.5465/amr.2007.23464011

Lieberman, M. B., Garcia-Castro, R., \& Balasubramanian, N. (2017). Measuring value creation and appropriation in firms: The VCA model. Strategic Management Journal, 38(6), 1193-1211. doi:10.1002/smj.2565

Lin, L., \& Wu, J. (2010). Virtual value chain and competitive advantages in the context of e-commerce. Paper presented at 2010 IEEE 17Th International Conference on Industrial Engineering and Engineering Management, Xiamen, China. Retrieved from https://www.researchgate.net/publication/251971660_ Virtual_value_chain_and_competitive_advantages_in_the_context_of_e-commerce. DOI: 10.1109/ICIEEM.2010.5646044

Lyon, T. P., Delmas, M. A., Maxwell, J. W., Bansal, P., Chiroleu-Assouline, M, Crifo, P., et al. (2018). CSR needs CPR: Corporate sustainability and politics. California Management Review, 60(4), 5-24. doi:10.1177/0008125 618778854

Mackey, A., Mackey, T. B., \& Barney, J. B. (2007). Corporate social responsibility and firm performance: Investor preferences and corporate strategies. Academy of Management Review, 32(3), 817-835. doi:10.5465/amr.2007. 25275676

McKee, A. (2017). Happiness traps: How we sabotage ourselves at work. Harvard Business Review, 95(5), 66-73.

Mirvis, P. H. (2012). Employee engagement and CSR: Transactional, relational, and developmental approaches. California Management Review, 54(4), 93-117. doi: 10.1525/cmr.2012.54.4.93 


\section{Stakeholders-Based Management}

Mitchell, R. K., Van Buren, H. J., Greenwood M., \& Freeman, R. E. (2015). Stakeholder inclusion and accounting for stakeholders. Journal of Management Studies, 52(7), 851-877. doi:10.1111/joms.12151

Nicolescu, O., \& Nicolescu, C. (2011). Organizaţia şi managementul bazate pe cunoştinţe. București, România: Pro Universitaria.

Pirson, M. (2017, June 12). What is humanistic management? Retrieved from http://humanisticmanagement.international/what-is-humanistic-management/

Porter, M. (1985). Competitive advantage: Creating and sustaining superior performance. New York: Free Press.

Rampersad, R. (2017). Corporate social responsibility: Applying sustainability principles in stakeholder engagement. Corporate Ownership \& Control, 14(2-1), 222-229. doi:10.22495/cocv14i2c1p8

Rayport, J. F., \& Sviokla, J. (1995). Exploiting the virtual value chain. Harvard Business Review, 73(6), 75-85.

Sachs, S., Rühli, E., \& Kern, I. (2009). Sustainable success with stakeholders: The untapped potential (1st ed.). Basingstoke, UK: Palgrave Macmillan. doi: $10.1057 / 9780230271746$

Schrempf-Stirling, J., Palazzo, G., \& Phillips, R. A. (2016). Historic corporate social responsibility. Academy of Management Review, 41(4), 700-719. doi: 10.5465/amr.2014.0137

Tantalo, C., \& Paton, B. (2013). Value innovation through value co-creation: The stewardship model in an italian SME. Proceedings of the International Association for Business and Society, 24, 240-251. doi:10.5840/iabsproc 20132425

Van Vliet, V. (2010). Virtual value chain model. Retrieved from https:// www.toolshero.com/problem-solving/virtual-value-chain/

Von Kimakowitz, E., Pirson, M., Spitzeck, H., Dierksmeier, C., \& Amann, W. (Eds.). (2011). Humanistic management in practice. Basingstoke, UK: Palgrave Macmillan. doi:10.1057/9780230306585

Voronov, M., \& Weber, K. (2015). The heart of institutions: Emotional competence and institutional actorhood. Academy of Management Review, 41(3), 456-478. doi:10.5465/amr.2013.0458

Wang, S. (2015). Chinese strategic decision-making on CSR. Berlin Heidelberg, DE: Springer Verlag. doi:10.1007/978-3-662-44997-4

Weiber, R., \& Kollmann, T. (1998). Competitive advantages in virtual markets - Perspectives of "information-based marketing” in cyberspace. European Journal of Marketing, 32(7/8), 603-615. Retrieved from https:// www.researchgate.net/publication/247614357_Competitive_Advantages_ in_Virtual_Markets-Perspectives_of_\%27Information-Based_Marketing \%27_in_Cyberspace 10.1108/03090569810224010

Zadek, S. (2004). The path to corporate responsibility. Harvard Business Review, 82(12), 125-132.

Zott, C., \& Amit, R. (2010). Business model design: An activity system perspective. Long Range Planning, 43(2-3), 216-226. doi:10.1016/j.lrp. 2009.07.004 